[Vol. 102

\title{
NOTE
}

\section{THE GREENSTEIN ACT: THE NEED FOR A NEW APPROACH TO THE TREATMENT OF PSYCHOPATHIC CRIMINALS}

One unsolved problem in criminai administration is the disposition of criminals who do not meet the legal tests for insanity and yet suffer from mental disorders which make imprisonment inappropriate for them; the plight of such offenders in Pennsylvania is illustrated by three recent cases. Three volunteer firemen admitted setting twenty-one fires in a six-month period. It was later learned that the incendiary activities of two had started about ten years before with field fires and had gradually progressed from the burning of abandoned outbuildings to barns, homes, and automobiles. ${ }^{1}$ The firemen would ignite the blaze with rope fuses, return home until the siren sounded, and then rush back to aid in extinguishing the fire. A psychiatric examination showed that each knew the difference between right and wrong when the acts were committed, but suffered from mental abnormalities, two apparently being pyromaniacs. The county judge sentenced them to long prison terms despite his regrets that "we have no proper place to send them. We must send them to the Eastern Penitentiary. Perhaps in the future there will be penal institutions for the proper care of such individuals. If and when that happens, if I am still a judge, I shall seek to have them transferred." 2 The judge's comments are especially remarkable in view of the existence in Pennsylvania since 1933 of the Greenstein Act, ${ }^{3}$ which on its face would have permitted the sentencing of the defendants to a mental institution.

\section{The Current Dilemma}

These defendants are representative of that inexactly defined group of offenders medically classified as "psychopathic personalities." 4 The psychopath is not necessarily legally insane nor mentally deficient; nor is he generally deemed to reach the degree of abnormality amounting to psy-

1. This information was gathered from a personal interview (Feb. 5, 1953) with Mr. Earl H. Allen, chief detective of Delaware County.

2. The Evening Bulletin, Philadelphia, Sept. 18, 1952, p. 1, col. 1.

3. Pa. Stat. Ann. tit. 50, 11223 (Purdon Supp. 1952).

4. Because the term "psychopath" is vague and often abused, it offers little help in making any clear-cut psychiatric classification. See GUTTMACHER AND WEIHOFEN, Psychiatry and the Law 86 (1952) ; Kraines, The Therapy of the Neuroses ANd Psychoses 462 (2d ed. 1943) ; SMith, The Psychology of the Criminal 146-7 (1922); TAFT, Crminology 85-6 (Rev. ed. 1950) ; WoOd and Waite, Crime and Its Treatment 269, 273 (1941); Committee on Forensic Psychiatry, Group for Advancement of Psychiatry, Report No. 9, Psychiatrically Deviated Sex 
chosis, ${ }^{5}$ which is the degree commonly required for certifiability to a mental hospital. ${ }^{6}$ The psychopath does, however, suffer from a mental disorder, which is characterized by a compulsion to indulge in a particular kind or kinds of antisocial behavior, typically coupled with an inability to learn by experience. ${ }^{7}$ The psychopath may appreciate not only the wrongfulness of the act, but also the high risk of punishment, and yet feel impelled to indulge in the criminal conduct. ${ }^{8}$ Pyromania, kleptomania, and sex psychopathy are examples of the antisocial behavior with which this Note is concerned. ${ }^{9}$

There is no general agreement as to the cause of the psychopathic state, ${ }^{10}$ but it appears that complex personality factors, varying widely

OFFENDERS 1 (1950). For example, pyromaniacs (pathological firesetters) and kleptomaniacs (pathological thieves) are designated by some authorities as examples of "psychopathic states," Henderson AND GILlespIe, A TEXT-Book OF Psychiatry 387 (6th ed. 1944), Strecker, Ebaugh, and Ewalt, Practical Clinical Psychiatry 323 (7th ed. 1951), and by others as graphic illustrations of an "obsessive compulsive neurosis," a form of psychoneurosis, BRASOL, The Elements of Crime 344 (1927); Burt, The Young Delinguent 560 (1925); SMrth, op. cit. supra, at 109; STRECRER, BASIC Psychiatry 175 (1952) (compulsive "must" behavior); WoOD AND WAITE, op. cit. supra, at 273-4; Spirer, The Psychology of Irresistible Impulse, $33 \mathrm{~J}$. CRIM. L. \& Criminology 457, 460-1 (1943). But since "it is the process and not the label which is significant," (TAFT, CRIMINology 85-6 (Rev. ed. 1950)) for purposes of this Note it has been found helpful to set forth only in general terms the type of person likely to be included by the label "psychopath" simply to focus some of the considerations involved in the "process."

5. See Henderson and Gillespie, op. cit. supra note 4, at 381; Wood AND WAITE, op. cit. supra note 4, at 269 . A psychotic, generally, is one so divorced from reality that he is unable to appreciate the rights of others, cannot conform to the mores of his society, and is in "obvious disharmony with the responsibilities and expectations of everyday living." STRECKER, EBAUGH, AND EWALT, op. cit. supra note 4 , at 372 .

6. See table in Strecker, Ebaugh, and Ewalt, op. cit. supra note 4, at 69.

7. See GutTaracher aNd WeIHOFEN, op. cit. supra note 4, at 90; LANDIS AND Bolles, Textrook of Abnoraral Psychology $281-95$ (1950); Strecker, Ebaugh, AND EWALT, op. cit. supra note 4, at 310-1.

8. Ibid. See especially LANDIS AND Bolles, op. cit. supra note 7, at 285.

9. See note 4 supra, however, for the fact that all authorities do not agree on this classification.

10. For a summary of existing theories see LANdIS AND Borles, op. cit. supra note 7, at 291-4; Strecker, EBAUGH, AND Ewalt, op. cit. supra note 4, at 311-4. For the two allied states of pyromania and kleptomania, among the suggested geneses are hereditary, neurological, biochemical, psychological, or environmental factors, plus a possibility of organic disorders. HENDERSON AND GILLESPIE, op. cit. supra note 4 , at 384 . The most widely accepted view is that these particular activities are a relief phenomenon for repressed elements in mental life, the most significant of such elements being sex. See ETtinger, The Problem of CrIME 191-2 (1932); Glueck, Studies in Forensic Psychiatry 241-53 (1916); Healy, The Individual DelINQUENT 772 (1915); SMITH, op. cit. supra note 4, at 110; Karpman, Impulsive Neuroses and Crime: A Critical Review, 19 J. CrIm. L. \& CrImInology 575, 585, 587 (1929); Steke1, The Sexual Root of Kleptomania, 2 J. CRIM. L. \& CrIminology 239 (1911). Some writers go even so far as to draw a correlation with the menstrual or pregnancy periods in women. Pollack, The Crmminality of Women 125-35 (1950) ; Moir, Some Medical Aspects of Crime, 8 Medico-Legal and Crimnnologicar. REv. 111, 125-6 (1940). Other professed theories are that they are the result of an abnormal glandular condition (Schlapp aND SMrth, THE NEw Crrminology 213-20 (1928)), are founded on childhood impressions and patterns of behavior (Lorand, Compulsive Stealing, 1 J. CrIM. Psychopathology 247 (1940)), or originate in a desire to change an unbearable situation (BLEULER-BRILL, TEXTBOoK OF Psychiatry 538-9 (1951)). 
with the individual, combine to compel the antisocial behavior. ${ }^{11}$ Similarly, the treatability of these conditions cannot be discussed in any categorical manner, but some of the relevant factors according to current opinion can be indicated. Where the patient is rebellious, often the case with psychopaths, ${ }^{12}$ improvement is dubious, but where he is co-operative and anxious for treatment, satisfactory results may perhaps be obtained even though a long period of treatment may be necessary. ${ }^{13}$ One author states that even apparently hopeless cases can often be made to adjust in a controlled environment where little demand is made on them, and where they have no real responsibility; ${ }^{14}$ other authorities put little stock in any kind of therapy. ${ }^{15}$ Psychoanalysis extending over a long period of time ${ }^{16}$ or the more economical group psychotherapy ${ }^{17}$ are the most promising forms of treatment. ${ }^{18}$ Perhaps the most that can be said in the current state of psychiatric knowledge is that in determining prognostic trends, each offender must be carefully evaluated with regard to all of the factors in his character which relate to the cause, degree, and stage of his disability. ${ }^{19}$

In determining the disposition of a criminal, normally two alternatives exist today-either the criminal is found insane according to one of the two accepted legal tests, or he is imprisoned because he does not fulfill their requirements. ${ }^{20}$ In most jurisdictions, including Pennsylvania, the "right

11. See especially STrecker, Ebaugh, aNd Ewalt, op. cit. supra note 4, at 311-4.

12. See GutTMacher and WeIHofEN, op. cit. supra note 4, at 104; LANDis AND Bolles, op. cit. supra note 7, at 294. In this respect the "psychopath" differs from those classified as neurotics who normally seek help in treatment. Ibid.

13. See Henderson AND Gillespie, op. cit. supra note 4, at 392. Smitr, op. cit. supra note 4 , at $170-1$, concludes that for treatment by psychoanalysis two conditions are necessary: (1) desire on the part of the subject for a cure, and (2) sufficient time. With special regard to pyromania, one authority concludes that the offenders fall into two main groups-the first requiring intensive psychotherapy with a view toward quick rehabilitation, the second demanding extended periods of institutionalization. Lewis and Yarneld, Pathological Frresetring 393 (1951).

14. Kraines, op. cit. supra note 4 , at 463.

15. Strecker, Ebaugh, ANd Ewalt, op. cit. supra note 4, at 324. 588.

16. See Smith, op. cit. supra note 4 , at 110,171 ; Karpman, supra note 10 , at

17. This method was employed in Army Disciplinary Barracks and Rehabilitation Centers during World War II. GuTtMacher AND WeIHOFEN, op. cit. supra note 4 , at 105 .

18. It has been pointed out that electric shock therapy is not permanently beneficial. Noyes, Modern Cinnical Psychiatry 307 (3d ed. 1948).

19. See LEWIS AND YARNELL, op. cit. supra note 13, at 393.

20. Many states make statutory provision for commitment to mental hospitals or some other special treatment for prison inmates found to be insane. E.g., LA. Rev. Stat. tit. 28, \$59 (1950); Mrce. Stat. Ann. \$14:854 (1937); OHIo Gen. CoDe ANn. $\$ 1890-73$ (Page 1951); PA. Stat. ANn. tit. 50, 1223 (Purdon Supp. 1952). While such statutes generally seem to be aimed at insanity developed or discovered after commission of the crime, some of these statutes permit hospitalization of offenders with disorders not amounting to legal insanity. See text at note 42 infra.

A possible third alternative means of disposition is probation, available in all but certain crimes. See, e.g., PA. Stat. ANN. tit. 19, §1051 (Purdon 1930). However, such a procedure would appear undesirable in the case of impulse-ridden personalities. 
and wrong" test of M'Naghten's Case 21 is applied to determine legal insanity; since psychopaths do not meet this test, they are sent to prison in the same manner as other criminals. The result is manifestly undesirable, at least as our prisons are presently constituted. ${ }^{22}$ An attempted rehabilitation, not punishment, is required. ${ }^{23}$ Since these persons do not learn by experience and are impelled to their actions by obscure personality defects, ${ }^{24}$ ordinary legal sanctions can have little deterrent effect. The stigma of commitment to a penal institution, along with the impersonal and regimented atmosphere, ${ }^{25}$ is a formidable obstacle to treatment. ${ }^{26}$ Because of the complex personality problems presented by psychopaths, individual psychiatric study of each offender is a necessary prerequisite to a rational program of treatment; ${ }^{27}$ yet present prison psychiatric facilities are virtually non-existent. ${ }^{28}$ Moreover, there is a tendency for these personalities to create prison disturbances, and the repressive measures which result increase, rather than diminish, the psychopath's difficulties. ${ }^{29}$ While these disadvantages of prison exist to some extent with all criminals, they are especially acute with psychopaths whose full co-operation is a necessary concomitant of any attempted treatment. ${ }^{30}$

21. ". . . to establish a defence on the ground of insanity, it must be clearly proved that, at the time of the committing of the act, the party accused was labouring under such a defect of reason, from disease of the mind, as not to know the nature and quality of the act he was doing; or, if he did know it, that he did not know he was doing what was wrong." M'Naghten's Case, $10 \mathrm{Cl}$. \& Fin. 200, 210, 8 Eng. Rep. 718, 722 (1843). For the history of the criminal test of insanity in Pennsylvania see Keedy, Irresistible Impulse in Criminal Law, 100 U. of PA. L. REv. 956, 983 n.185 (1952).

22. Wood and WaIte, Crime and ITs Treatment 280-1 (1941); Pollock, The Mentally Ill in Pennsylvania Criminal Law and Administration, 12 U. of PITT. I. REv. 587, 601 (1951); Legis., 100 U. OF PA. L. REv. 727, 739-41 (1952).

23. "The treatment of this group has been taken over by legal authorities with the consequence that there is no treatment, but only punishment. These persons are ill, just as is the psychotic patient; and the habitual criminal is a socially sick person who may have a recoverable or an incurable illness, the true nature of which can be determined only by proper investigation. These psychopathic persons are today treated by society just as unintelligently as were the definitely mentally ill in the middle ages." KRAINES, op. cit. supra note 4, at 463 . See also CuRTIS, The LAw of ARson 116 (1936); Braun, Legal Aspects of Arson, 43 J. CRIM. L. \& CrIminology 53, 58 (1952); Karpman, The Principles and Aims of Criminal Psychopathology, 1 J. Crmi. Psychopathology 187, 209 (1940); Pollock, supra note 22 , at 601 .

24. See text at notes 10 and 11 supra.

25. The factors of impersonality and regimentation are discussed by LEwIS AND YARNELL, op. cit. supra note 13 , at 395 .

26. Legis., 100 U. of PA. L. Rev. 727, 740-1 (1952).

27. LEWIS AND YARNELL, op. cit. supra note 13, at 390, 393.

28. WOOD AND WAITE, op. cit. supra note 4, at 281-2. See also Note, The Legal Disposition of the Sexual P sychopath, 96 U. of PA. I. REv. 872, 875 (1948); Legis., 100 U. OF PA. I. REv. 727, 740 (1952).

29. See Singer AND KROHN, INSANITY AND LAW 152 (1924).

30. See text at notes 12 and 13 supra. Another feature of prison penology which has been criticized as contrary to a theory of individualization is the definite term of sentence. See, e.g., LEWIS AND YARNELL, op. cit. supra note 13, at 393-4; Note, The Legal Disposition of the Sexual Psychopath, 96 U. OF PA. L. REv. 872, 874 (1948); Glueck, Principles of a Rational Penal Code, 41 HARV. L. REv. 453, 480-1 (1928). However, consideration of the indeterminate sentence, which is fraught with procedural difficulties, is beyond the scope of this Note. For a discussion of the problems in regard to the indeterminate sentence in the Pennsylvania sex crime law see Legis., 100 U. OF PA. L. REv. 727 (1952). 
Commitment of psychopaths to existing mental hospitals, even where it is legally possible, ${ }^{31}$ is also subject to serious objection. State mental hospitals are already overcrowded and inadequate for the purposes they are presently intended to fulfill, 32 and cannot provide the prolonged and individualized therapy required for many psychopathic offenders. ${ }^{33}$ Moreover, mental hospitals are reluctant to admit psychopaths ${ }^{34}$ because these partially-responsible individuals tend to cause incessant trouble, with disturbing effects on the other inmates. ${ }^{35}$ Mental hospitals are not normally equipped to handle criminals. Penal supervision programs, inimical to the best interests of other inmates, are generally absent; yet it is important to have adequate security provisions to prevent the escape of psychopaths who often tend to be impulsive wanderers. ${ }^{36}$ Aside from the possibility of escape, there is the added danger in an institution not of the maximumsecurity type that an inmate, especially a pyromaniac, might carry out his impulses on the state institution. ${ }^{37}$ But, despite the severe inadequacies of mental hospitals for the treatment of the psychopathic criminal, it has been contended that commitment to such an institution, if of the maximumsecurity type, is generally the best solution offered by our present institutional system. ${ }^{38}$ In most jurisdictions, however, mental hospitals are not available to psychopathic criminals, for most psychopaths do not meet a definition of legal insanity as couched in terms of M'Naghten's "right and wrong" test. ${ }^{39}$ On the other hand, jurisdictions which include in the definition of the legally insane those subject to an "irresistible impulse" have recognized that some psychopaths fall within this category; ${ }^{40}$ a finding of insanity under this test would generally result in the commitment of the defendant as an insane person. ${ }^{41}$ In some states hospitalization of certain psychopathic criminals, particularly sex psychopaths, is made possible by

31. See text at note 39 infra.

32. Pollock, supra note 22 , at $600-1$.

33. See text at note 13 supra.

34. For an example of the reluctance of mental hospitals in this area see Commonwealth v. Leeds, 32 Del. County Rep. 412, 417 (Pa. 1942). See also SINGER and KROHN, InSANITY and LAw 152 (1924).

35. Id. at 151-2.

36. Lewis and Yarnell, Pathological Firesetting 394-5 (1951).

37. For an illustration of an attempt to set fire to the incarcerating institution see Guttmacher and Weinofen, Psychiatry and the Law 59 (1952).

38. In LEWIS AND YARNELL, op. cit. supra note 36, at 396, from the presently available alternatives for the incarceration of psychopaths the authors choose the institution for the criminally insane over prisons. They also suggest, however, at 394-5, that for certain types of offenders modern prisons are better than existing mental hospitals.

39. See text at and notes 20 and 21 supra.

40. For example, kleptomaniacs have been held to be included within this test. E.g., State v. McCullough, 114 Iowa 532, 87 N.W. 503 (1901); see Note, 43 L.R.A. (N.S.) 150 (1913). The fact that they are so included has even been used as an argument for the wider adoption of the irresistible impulse test. Hall, Mental Disease and Criminal Responsibility, 45 CoL. L. Rev. 677, 704 (1945). Pyromania would also appear to be included. See Smoot, LAW of INSANITY 54 (1929).

41. Weinofen, Insantty as a Defense in Criminal Law 266-76 (1933). See, e.g., PA. Stat. ANN. tit. 50, §1221 (b) (Purdon Supp. 1952). 
specific statutory provision containing no requirement of "legal insanity." 42 In Pennsylvania the Greenstein Act ${ }^{43}$ offers the further possibility of discretionary commitment of any psychopathic criminal to a mental hospital, despite the fact that psychopaths generally do not meet the Pennsylvania legal insanity test. ${ }^{44}$ This statute should be examined in the light of the failure of the judge to utilize it in the introductory cases, despite his reluctance to imprison the defendants.

\section{The Greenstein ACT}

The language of the Greenstein Act does not compel the conclusion that the Pennsylvania legislature intended to permit psychopathic offenders to be committed to other than penal institutions; imprecise draftsmanship leaves the Act's coverage somewhat equivocal. The Act, as incorporated in the Mental Health Act of 1951, provides that:

"Whenever any person is convicted of a crime punishable by sentence to a penal or correctional institution, the trial court may defer sentence and order a mental examination of the defendant to guide it in determining his disposition.

"On report of the examiner that the defendant is so mentally ill or defective that it is advisable for his zelfare or the protection of the community that he be committed to other than a penal or correctional institution, the court may commit him . . . to a State institution for the care of such mental cases in lieu of sentence to a penal or correctional institution. . . ."45

42. See, e.g., CaL. Welfare and Institutions Code $\$ 5502$ (Deering 1944); 10 Orio Gen. Code Ann. \$13451-20 (Page Cum. Supp. 1952) ; Pa. Stat. Ans. tit. 19, $\$ 1166-1174$ (Purdon Supp. 1952) (sex crime law). For a general discussion of the sex psychopath laws see Gutramacher and WeIHoren, Psychiatry and the LAW 123-37 (1952).

43. PA. Stat. Ann. tit. 50, §1223 (Purdon Supp. 1952).

44. For the fact that Pennsylvania employs the "right and wrong" test see Keedy, supra note 21 , at 983 n. 185 .

45. Pa. Stat. AnN. tit. 50, §1223 (Purdon Supp. 1952) (Italics added). This statute was first enacted in 1933 and amended in 1935 to provide for a right of appeal ( $\mathrm{Pa}$. Laws 1935, P.L. 352, \&1); has since been incorporated, for the most part unchanged, in the Mental Health Act of 1951 (PA. STAT. ANN. tit. 50, $\$ 1071-$ 1622 (Purdon Supp. 1952), amended, immaterially for the purposes of this Note, in 2 Pa. Laws 1951-52, P.L. 2053); and has received the indorsement of the Group for the Advancement of Psychiatry (Committee on Forensic Psyceiatry, Grous For the Advancearent of Psychiatry, Report No. 9, Psychiatricalix Deviated SEX OFFENDERS 3 (1950): "The Committee regards this law as applied to convicted offenders as commendable for both simplicity and comprehensiveness."). The Act generally provides for the deferring of sentence after conviction for a mental examination of the defendant on the initiative of either the court itself, the district attorney, the defendant, or a person acting in the defendant's interest; an examination and written report by a psychiatrist which shall be available to the court, district attorney, and defendant's counsel; and, where the court deems it advisable, commitment of defendant to a mental institution instead of a prison, where he will be detained until further order of the court. Compare the provisions of the Greenstein Act with those of the recently enacted defective delinquent statute of Maryland: "The Board of Correction is authorized in its discretion to transfer into the Patuxent Institution any person sentenced to or confined in ... [Maryland penal institutions]. Such transfer may be made at any time the Board, in its discretion, de- 
The coverage of the Greenstein Act has never been judicially delineated. Its scope depends on which of three possible definitions of the statutory phrase "mentally ill" ${ }^{46}$ is accepted. These three possibilities are: (1) that "mentally ill" refers only to persons who are "insane" in the legal sense, (2) that it refers to persons who are certifiable under the present practices of state mental hospitals, or (3) that it can be construed to apply to personality deviations less serious than these, but which the psychiatrist and judge feel justify other than penal incarceration.

(1) It is clear that the Greenstein Act goes beyond the usual definition of legal insanity as formulated in $M^{\prime}$ Naghten's Case ${ }^{47}$ since the Act applies only after conviction, a conviction ordinarily being impossible if the defendant was "insane" when the crime was committed. ${ }^{48}$ In addition, the legislation from which the Act evolved provided for defendants who were mentally ill "though not insane". ${ }^{49}$ It would thus be untenable to construe "mentally ill" here to embrace only those who are legally insane.

(2) An argument for an application of the Act to a comparatively narrow area beyond the limits of legal insanity is that the phrase "mentally ill" should be defined to include only those persons who according to current hospital practices are considered committable to mental institutions. ${ }^{50}$ In

termines that it would improve discipline or aid in the safekeeping, treatment, training, employment or rehabilitation of such person." A defective delinquent is defined by the act as a person "who, by the demonstration of persistent aggravated antisocial or criminal behavior, evidences a propensity toward criminal activity, and who is found to have either such intellectual deficiency or emotional unbalance, or both, as to clearly demonstrate an actual danger to society so as to require confinement and treatment under an indeterminate sentence, subject to being released only if the intellectual deficiency and/or the emotional unbalance is so relieved as to make it reasonably safe for society to terminate the confinement and treatment." Detailed procedures are required to be followed before an individual can be designated a defective delinquent. Maryland Laws 1951, c. 476, §\$ 4(C), 5, 6-11.

46. The Act applies to the "mentally defective" as well as to the "mentally ill," but the former category will be disregarded for purposes of this Note. "Mentally defective" has a generally accepted technical meaning, i.e., defective in mental capacity, as feebleminded. NOyes, Modern Cinnical Psychiatry 424-5 (3d ed. 1948). Separate institutions have been established for the care and treatment of such persons.

47. See note 21 supra.

48. There is, of course, the possibility that a legally insane person can be convicted because he did not raise the defense of insanity, or because a jury rejected the defense although insanity is apparent to the judge.

49. For the text of the original Act see Pa. Laws 1933, P.L. 224. The legislative history of the present Mental Health Act of 1951, in which the Greenstein Act appears in its altered form, indicates that it was simply a codification of existing law and that no substantive changes were intended by it. 2 PA. LegisLative JoURNAL 1158 (1951). ". . . this bill ... is a codification of the laws as they now appear on the statute books. The mental health laws were gathered together and put into this code ... for the purpose of effecting immediate amendments to it. If this bill is passed and sent over to the Governor for his signature, and if the Governor signs the bill, it will not change the existing law one iota. This is the laze as it is today." (Italics added). Senator John M. Walker, Chairman, Senate Rules Committee, id. at 2022-3.

50. According to the Mental Health Act of 1951, requirements for voluntary admission are that the superintendent find that the applicant is mentally competent to seek admission, is in need of care and will be benefited by admission. PA. STAT. ANN. tit. 50, \$1162 (Purdon Supp. 1952). Where application is by a relative or friend, two physicians must certify that the patient is or is thought to be mentally 
actual practice, the class of persons denominated committable consists largely of those labeled psychotic by the medical profession, generally excluding deviates such as psychopaths. ${ }^{\text {51 }}$ Under this definition of "mentally ill" a defendant would have to be certifiable before the statute's descriptive words following "mentally ill" are applicable, i.e., he must be certifiable before the judge can even consider the advisability for his or the community's welfare of committing him to a mental hospital rather than a prison. It might be argued that administratively this is the only practical interpretation-that it would be unrealistic to ask judges to deal in distinctions any less clear than that between criminals who are psychotic and those who are not; and that if present mental hospitals are to be the receiving institutions, it is unreasonable to send them criminals with conditions which might not meet their admission requirements for non-criminals.

(3) On the other hand, the language of the Greenstein Act could be interpreted to cover any mentally abnormal defendant, as long as the sentencing judge considered non-penal commitment advisable for the defendant's or the community's welfare. This construction results from defining the phrase "mentally ill" in light of the phrase concerning the advisability of non-penal commitment.52 Such an interpretation would allow the judge in each case of mental abnormality to determine whether or not the requisite mental illness is present on the basis of whether or not non-penal commitment is advisable.

Prior mental health provisions and their construction by the courts provide additional arguments for a definition of "mentally ill" which includes more than persons ordinarily certifiable. ${ }^{53}$ Section 308 of the Mental Health Act of 1923 in part provided for commitment to a mental hospital of a person detained in prison awaiting trial or undergoing sentence who was "insane, or in such condition as to make it necessary that he be cared for in a hospital for mental diseases." 54 This quoted phrase was held in Commonrealt $\dot{h} v$. Schirmer ${ }^{55}$ to include not only those legally insane, but

ill or is in need of and will be benefited by admission. Id. $\$ \S 1181-1182$. For commitment of non-criminals by a court a commission of two physicians and an attorney must find that the person is mentally ill and a proper subject for admission, or is a proper subject for care, or that the public welfare requires commitment. Id. $\S \S 1202-1203$. The requirements of any of these provisions could be interpreted so as to be met by the defendants in the instant case, but actual hospital requirements for those being admitted are usually more restrictive. See note 6 supra and text at note 66 infra.

51. For a discussion of the fact that mental hospitals have refused to admit other than psychotic patients, see note 6 supra and text at note 66 infra.

52. See italicized portion in text at note 45 supra. This view is advanced in Pollock, The Mentally Ill in Pennsylvania Criminal Law and Administration, 12 U. OF PITT. L. REv. 587, 600-1 (1951), and is strengthened by the fact that the mental examination is to be secured "to guide it [the trial court] in determining his [the defendant's] disposition." PA. Stat. ANN. tit. 50, §1223(a) (Purdon Supp. 1952).

53. See note 49 supra for the fact that the present Act is merely a codification of existing law.

54. Pa. Stat. Ann. tit. 50, $\$ 48$ (Purdon 1931), repealed in Pa. Stat. Ann. tit. 50, 1621 (Purdon Supp. 1952).

55. $32 \mathrm{~Pa}$. D. \& C. 36 (1938). See also Commonwealth v. Leeds, 32 Del. County Rep. 412 (Pa. 1942). 
also "all cases of the mentally ill who may reasonably be said to require institutional care and restraint." 56 Thus, "mentally ill" was construed to cover one who was apparently a sex psychopath. ${ }^{57}$ Moreover, since at the time the Greenstein Act was passed there already existed this provision in the 1923 Act for the commitment of at least all prisoners who were certifiable, it appears that the purpose of the Greenstein Act must have been to extend the sentencing discretion of the judge to allow commitment to mental institutions of defendants who are not necessarily certifiable under present practices. ${ }^{58}$

Finally, while this third interpretation of the Greenstein Act is not the only possible one, it is the one most consonant with the aims of the medical profession. For many years a central goal of this profession has been individualization of criminals through psychiatric examination and a further application of psychiatry in treatment if the examination shows it to be warranted. ${ }^{59}$ As a step toward accomplishing the desired individualization, the Act should be interpreted to mean that all convicted criminals shown by prior psychiatric examination to be in need of institutional psychiatric care rather than prison incarceration should be placed, at the judge's discretion, in an institution where this care is properly available. So interpreted, the Greenstein Act points toward a new approach to the problem of the criminal psychopath.

56. 32 Pa. D. \& C. $36,41-2$ (1938).

57. After defendant pleaded guilty to an indictment for indecent assault, sentence was deferred and a commission appointed to examine him under the old Mental Health Act. The commission found that although he was not insane in the medical and technical meaning of the word, defendant was in such condition as to necessitate mental hospital care. The court held that it nevertheless had power to commit him to Farview State Hospital for the criminally insane, and itself described the defendant as a "dangerous psychopath." The defendant admitted that he appreciated the nature and character of his criminal impulses, but confessed his inability to control them. He claimed that he afterwards regretted having committed the acts to which he was driven by his impulses. Id. at 38 .

58. It is unlikely that the Greenstein Act added anything new in providing for commitment after conviction and before sentencing, for Section 308 also applied "on the production or appearance of any person charged with criminal offense, or on the production or appearance before the court of such person under any other circumstances. . . " (Italics added). PA. Stat. ANN. tit. 50, § 48 (Purdon 1931), repealed in PA. Stat. Ann. tit. 50, \$1621 (Purdon Supp. 1952). This would seem to apply to persons appearing before the judge for sentencing after conviction. Nor did the Greenstein Act add materially to existing investigative procedures. Section 308 provided for an inquiry by either two qualified physicians or a commission made up of two physicians and a lawyer. These persons were then to make a report, and from this plus any additional evidence he might think necessary, the judge in his discretion could order the individual's commitment to a mental hospital. Compare the investigational provisions in the Greenstein Act discussed in note 45 supra.

59. Glueck, Principles of a Rational Penal Code, 41 Harv. L. Rev. 453, 462-82 (1928). See also Arnold, Imsanity and Criminal Responsibility, $10 \mathrm{~J}$. CRIMr. L. \& CrImINologY 184 (1919); Dession, Psychiatry and the Conditioning of Criminal Justice, 47 Y ALE L.J. 319 (1938); Karpman, An Attempt at Re-evaluation of Some Concepts of Laze and Psychiatry, 38 J. CRIM. L. \& CRTMInologY 206, 215-6 (1947); Menninger, Medicolegal Proposals of the American Psychiatric Association, $19 \mathrm{~J}$. CRIM. L. \& CRIMINology 367, 373-7 (1928); Miller, A Plea for Selective Psychiatric Treatment for Offenders, 37 J. CRIM. L. \& CRIMINologY 377 (1947) ; Overholser, The Place of Psychiatry in the Criminal Law, 16 B.U.L. REv. 322, 338-44 (1936); Perkins, Partial Insanity, 25 J. CRIM. I. \& CRIMINology 175, 182-6 (1934). 


\section{The Institutional Solution}

Interpreting the Greenstein Act in the light of the above discussion, the judge in the introductory cases was not required by legal considerations to imprison the defendants. Other considerations, however, compelled imprisonment. The Greenstein Act's apparent solution to the problem of the criminal psychopath is in fact illusory, partly because the Act is little known, but chiefly because the alternative institutions to which psychopaths could be sent under the Act are totaily unavailable. The provisions of the Act have been rarely applied, ${ }^{60}$ and probation officers appear to be almost wholly ignorant of its existence. ${ }^{61}$ Correspondence with the superintendents of the state mental hospitals confirms the conclusion that the Act in practice does nothing but solve a procedural-investigational problem. ${ }^{62}$ Even for this purpose many courts used similar provisions in the old Mental Health Act of $1923,{ }^{63}$ rather than the pertinent provisions of the Greenstein Act.

The primary cause of the Act's ineffectiveness has been the lack of adequate facilities to carry out its purpose. ${ }^{64}$ Mental hospitals, for the reasons discussed above, ${ }^{65}$ have been loathe to admit psychopaths; and since judges desired the hospitals' continued cooperation for investigational purposes, they could hardly compel the superintendents to comply with the

60. On the appellate level the Act has been discussed by only two cases, neither of which is important for present purposes. Commonwealth v. Iacobino, $319 \mathrm{~Pa}$. 65, 178 Atl. 823 (1935); Commonwealth v. Green, 346 Pa. 172, 29 A.2d 491 (1943). It is also interesting to note that in one use of the Act reported on the appellate level, it was applied to a defendant who was improperly tried while insane and convicted on what was in effect a directed verdict. Commonwealth v. Ragone, 317 Pa. 113, 176 Atl. 454 (1935). Since the Act would be invoked, if ever, on the trial level, it is uncertain just how often it has been applied. But the superintendents of the state mental hospitals and the Department of Welfare are in almost unanimous agreement that the Act is seldom used for commitment purposes. In a communication to the University of Pennsylvania Law Review (Dec. 10, 1952) Dr. Hilding Bengs, Commissioner of Mental Health, summed the matter up by saying: "Although the statute was enacted May 2, 1933, as related legislation to the Mental Health Act of 1923, it was used so infrequently up to last year that it was practically inactive... .

"Even within the past year I doubt that it has been used more than half a dozen times. . . I know only of two instances where it was used to commit defendants to a state mental institution." This letter and other communications referred to in this Note are on file in Biddle Law Library, University of Pennsylvania Law School.

61. This was learned from communications to the UnIversity of Pennsylvania LAw REvIEw. In one such letter a probation officer when informed of the existence of the Act stated: ". . . we feel that this is a very good Act and will be used quite frequently. Not being familiar with the Act, I will be unable to give you any further information."

62. These superintendents indicated that of all provisions of the Act, that providing for psychiatric investigation is used most. There is no indication, however, that even this provision has been used with any degree of frequency.

63. Pa. Stat. Ann. tit. 50, $\$ 47$ (Purdon 1931), repealed in Pa. Stat. Ann. tit. 50, \$1621 (Purdon Supp. 1952). It should be noted that this section covered only a person "thought to be mentally ill;" the Greenstein Act covers all convicted defendants.

64. See Pollock, supra note 22, at 600-1.

65. See text following note 31 supra. 
Act, even where they felt that the Act applied. ${ }^{68}$ Only Farview, the Pennsylvania institution for the criminally insane, is a mental institution of the maximum-security type adapted to the incarceration of criminals requiring psychiatric care, but presently it is $35 \%$ overcrowded and has no segregation facilities for the disturbing psychopaths. ${ }^{87}$ But despite the practical objections to its present operation, most superintendents thought the Act a proper solution to the problem of the psychopath, were there facilities enough to carry out its provisions. ${ }^{68}$ Others expressed doubts as to whether the expense would be justified in the present state of our knowledge; a few thought most criminals were psychopathic but should nevertheless be imprisoned; and only one thought the Act was now effective-he being the superintendent of the only state mental hospital which is not working above its rated capacity. ${ }^{69}$

Thus, on the whole, the apparent solution to the problem as offered by the Greenstein Act cannot be invoked and, as in the instant cases, judges can only sentence to prison persons falling within its scope, despite their doubts as to the appropriateness of that institution. Similar problems have arisen under the growing body of sex crime laws ${ }^{70}$-there are none but penal or inadequate mental institutions to which to commit sex psychopaths. ${ }^{71}$ Only a new and different institution with a staff trained for the prolonged therapy and custody required in the care and treatment of psychiatrically deviated offenders can offer hope of a solution to the prob$1 \mathrm{em},{ }^{72}$ but as yet only one state seems to have taken any steps in this direc-

66. This was the major ground stated by the judge in the introductory cases for his failure to invoke the provisions of the Act. In order to maintain co-operation with mental hospitals to fulfill any investigational needs, he had to refrain from attempting any forced compliance with the commitment provisions of the Act.

67. Dr. John P. Shovlin, superintendent of Farview State Hospital, in a communication to the UNIversity of Pennsylvania Law Review (Dec. 12,1952).

68. The superintendents so indicated in communications to the UNIVERSITY oF Pennsylvania Law Review. In one such communication (Dec. 8, 1952) Judge Burton R. Laub of the Sixth Judicial District (Erie) concisely summarized the problem when he said: "The act is a forward step along the road to solution if the State follows through with the establishment of appropriate institutions."

69. This favorable report was received from Embreeville State Hospital which, although the smallest in the state, is only $95 \%$ occupied. 90 PenNsylvania Manual 995 (1951-52).

70. For a summary of this legislation see Legis., 100 U. of PA. L. REv. 727 (1952). It has been said that the only pragmatic justification for this separate sex psychopath legislation is that it permits testing of new procedures in a limited area, which may constitute an opening wedge for extension of similar procedures to other psychiatrically deviated offenders. GUTTMacher and WeIHOFEn, Psychiatry and THE LAW 133 (1952).

71. GutTMacher aNd Weinofen, op. cit. supra note 70, at 133-4; Legis., 100 U. OF PA. L. REv. 727, 738-41 (1952). As a striking example of this difficulty, Judge Laub, supra note 68, cited the case of a sex offender whose problem was certified to the Department of Welfare for designation, pursuant to the new Act, of the institution to which he should be sentenced. The Department designated the Western State Penitentiary-the same institution to which the judge would have sentenced him prior to the Act.

72. See Lewis and Yarnell, Pathological Ftresetring 390 (1951); Singer AND KROHN, INSANITY AND LAw 414-5 (1924); Pollock, The Mentally Ill in Pennsylvania Criminal Law and Administration, 12 U. oF PITT. L. REv. 587, 601 (1951). There is such an institution for sex offenders in Denmark. Tappan, Treatment of the Sex Offender in Denmark, 108 AM. J. Psychiatry 241, 247 (1951). 
tion..$^{73}$ If the legislature is not yet willing to progress this far, in view of the doubts of some psychiatrists as to the efficacy of treatment, it should at the very least found an institution of more limited scope to demonstrate through a research program ${ }^{74}$ the extent to which psychopathic cases are responsible for criminality and what positive treatment skills exist, in order to make clear to the taxpaying and voting public whether the need is urgent and the expense justified. Only then will special care and treatment facilities of a permanent type be foreseeable. The kind of institution advocated by psychiatrists (including many of the present hospital superintendents) is a classification and specialized treatment center, "a colony system, something between the prison and the mental hospital, where persons showing such tendencies could be maintained and treated while learning to develop a sense of responsibility." 75 The institution might be an entity in itself, or perhaps a building or wing of an existing mental hospital, if that is the most the community will underwrite. Basic to the effectiveness of any such institution are adequate staffing and a program of continuing research. In order to fill both these needs, the facilities should be established in metropolitan areas, close to or in conjunction with existing medical centers, making possible the enlistment of the best psychiatric talent. ${ }^{76}$

\section{Conclusion}

The Greenstein Act has existed in substantially its present form for twenty years, a form which is capable of liberal interpretation to include all convicted criminals requiring psychiatric treatment. Nevertheless, while the Act offers a rational approach to the problem illustrated in the introductory cases, it has been seldom used because none of the existing mental institutions provide the type of facilities needed for the psychopathic case. The next step should be further research and a new institution adapted to these personality states, with the necessary staff to implement it.

73. Maryland Laws 1951 , c. 476 . The institution planned under the provisions of the Maryland statute is discussed in GUTTMACHER AND WEIHOFEN, op. cit. supra note 70 , at 106 . Generally it provides for three separate divisions: the first will be a diagnostic center in which criminals will be intensively studied, and which will be engaged in active research; the second will be of the minimum-security type to house intellectually defective delinquents; and the third will be of maximum security to contain the psychopathic and neurotic habitual criminals.

74. Such a research program was established in California for sexual psychopathy when that state appropriated $\$ 100,000$ to initiate research "into the causes and cures of sexual deviation." Cal. Stat. First Extraordinary Sess. 1950, c. 35.

75. Henderson and Gillespie, A Text-Book of Psychiatry 393 (6th ed. 1944). See also Burt, The Young Delinquent 571-2 (1925); Wood and Waite, Crnme and its Treatarent 280-1 (1941); Kraines, The Therapy of the Neuroses and Psycenoses 463 (2d ed. 1943) ("Society, however, has as yet not advanced to the point where it realizes its responsibility for furnishing large semi-hospital units where persons with psychopathic traits can live a useful and constructive life in a controlled and directed milieu.").

76. This has been suggested by Pollock, supra note 72, at 601. Another advantage of a metropolitan center would be the availability of student and part-time talent. 
The legislature has created in the Greenstein Act an illusory solution to the present problem; it should now progress further and bring that solution into reality. ${ }^{77}$

77. For a comprehensive discussion of the existing gap between proposal and implementation in the criminal psychiatric field, see Dession, Psychiatry and the Conditioning of Criminal Justice, 47 YALE L.J. 319 (1938). This writer concludes at 327-8: "Individualization of disposition and rehabilitation of offenders, if by these slogans we mean something more than ordinary leniency, have to date been hatched out of idea into realization only in scattered instances. . . it is in the inherited tradition to assign a great deal more work to our agencies of criminal law administration than we would ever dream of equipping them to perform . . . . what we have traditionally sought of criminal justice has been not so much actual as symbolic performance." 